\title{
SYLVIA AND THE ABSENCE OF LIFE BEFORE TED*
}

\author{
Mariana Chaves Petersen* \\ Instituto Federal de Educação, Ciência e Tecnologia do Rio Grande do Sul
}

\begin{abstract}
As Bronwyn Polaschek mentions in The Postfeminist Biopic, the film Sylvia (Christine Jeffs, 2003) is based on biographies of Sylvia Plath that focus on her relationship with husband Ted Hughes - such as Janet Malcolm's The Silent Woman. In this paper, grounded in the works of Linda Hutcheon, Mary E. Hawkesworth, and Tracy Brain, I argue that this biography works as a palimpsest of Sylvia and that the film constructs Plath as the Ariel persona, neglecting her "Juvenilia" - her early poetry, as it has been defined by Hughes. Sylvia actually leaves Plath's early life - before she met Hughes - aside and it thus ends up portraying her more as a wife than as a writer. Finally, by bringing information on Plath's life before she met Hughes from a more recent biography (by Andrew Wilson), I analyze how a different image of Plath might have been created if this part of her life were not missing in the film.
\end{abstract}

Keywords: Sylvia. Sylvia Plath. Adaptation studies. Biopic. Feminist criticism.

She wanted to be everything, I think. She was always searching for the self that she was going to be.

— Elinor Friedman Klein, qtd. in Andrew Wilson, Mad Girl Love's Song

How can you be so many women to so many people, oh you strange girl?

— Sylvia Plath, from her journals

\section{Introduction: a chosen branch}

Several were the attempts to fictionalize Sylvia Plath by making her a character in novels, poems, films, and biographies. Directed by Christine Jeffs, the 2003 film Sylvia is

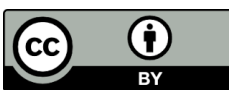

Esta obra está licenciada sob uma Creative Commons - Atribuição 4.0

\footnotetext{
* An earlier version of this paper was presented at the eleventh Annual Association of Adaptation Studies Conference at St. Anne's College, Oxford, U. K.

* Teacher of Portuguese and English at Instituto Federal de Educação, Ciência e Tecnologia do Rio Grande do Sul. Master of Arts in Literature Studies - English Language Literatures (2017) and Teaching Degree in Portuguese Language and Literature, English Language and Literature (2015), both by Universidade Federal do Rio Grande do Sul. Lattes: http://lattes.cnpq.br/6054074534692638. ORCID: http://orcid.org/0000-0002-58506683. Email: marianacpetersen@gmail.com.
} 
biopic about Plath's life - though a small part of it, as we will see. ${ }^{1}$ While other fictionalizations of Plath are not so evidently about her, Tracy Brain (2011, p. 184) sees in Sylvia "the obvious efforts of a biopic." The film can also be seen as an example of historiographical metafiction, and it has already been analyzed as a postfeminist biopic, both of which I will further discuss. The film relies on biographies written on Plath, mostly on the ones that focus on her relationship with her husband, Ted Hughes - of whom she was separated when she died. Thus, Sylvia's emphasis is mostly on their relationship, more than on the depiction of Plath as a writer. This text is an attempt to critically discuss this film and also to bring information that is missing in it; by doing so, I hope to call attention to what this production left aside that could have helped to shape the character Sylvia more as a creative woman than as a wife.

Of course it is necessary to make a selection of which events will be shown in a film: Sylvia begins on the day that Plath met Hughes to later fill in the gaps of her past. It starts in Ted's England, rather than in Sylvia's U. S. - though, at the end of her life, England would also be hers. However, the film's focus on their marriage is excessive: Sylvia's most recurrent scenes are portrayals of a desolate and jealous wife, waiting for hours for her husband to come home. Among important elements of Plath's life that are put aside in the film, are relationships such as the ones with her mother, her friends, and her children. ${ }^{2}$ Her creative process is also almost absent from Sylvia: there are few scenes in which she is writing poetry, and we never get to see the writing process of The Bell Jar - the novel is only mentioned after it is already finished.

As a young woman, Plath suffered with the task of choosing between alternatives for her life, and the scene that opens Sylvia is actually emblematic of her anxieties. We see an image of the tree of life (Figure 1), after Sylvia's (Gwyneth Paltrow) in-off voice narrates the several possibilities available to her:

\footnotetext{
${ }^{1}$ As far as possible, to avoid confusion between Sylvia Plath and Sylvia's fictionalization of her, I will try to call the person "Sylvia Plath" or just "Plath," and the character, "Sylvia."

${ }^{2}$ Brain (2011, p. 189) criticizes the fact that, in the film, Sylvia appears preparing a bottle of formula to feed her baby, and not breastfeeding, which was central to Plath's "writing" and "sexual politics"; according to her, "the omission deprives [the audience] of an awareness of Plath's interest in women's roles as mothers and in the female body" (BRAIN, 2011, p. 189). Motherhood is indeed one of the most recurrent themes in Plath's poetry and prose. It is the center point of the dramatic poem - written for the radio - Three Women, and it is also treated in poems such as "Metaphors," "You're," "Morning Song," "Nick and the Candlestick," and "Child," among many others (see Plath, The Collected Poems, 2008a). Furthermore, Aurelia Schober Plath, Plath's mother, had a central - though ambivalent - role in her life, as it is possible to observe in their correspondence, published in Letters Home. A mother figure was also recurrent in Plath's poems - such as "The Disquieting Muses" and "Medusa" - and is of high importance in her prose - especially in The Bell Jar.
} 
Sometimes I dream of a tree, and the tree is my life. One branch is the man I shall marry, and the leaves, my children. Another branch is my future as a writer. And each leaf is a poem. Another branch is a glittering academic career. But as I sit there trying to choose, the leaves begin to turn brown and blow away, until the tree is absolutely bare. (SYLVIA, 2003, ch. 1).

Figure 1: The tree of life.

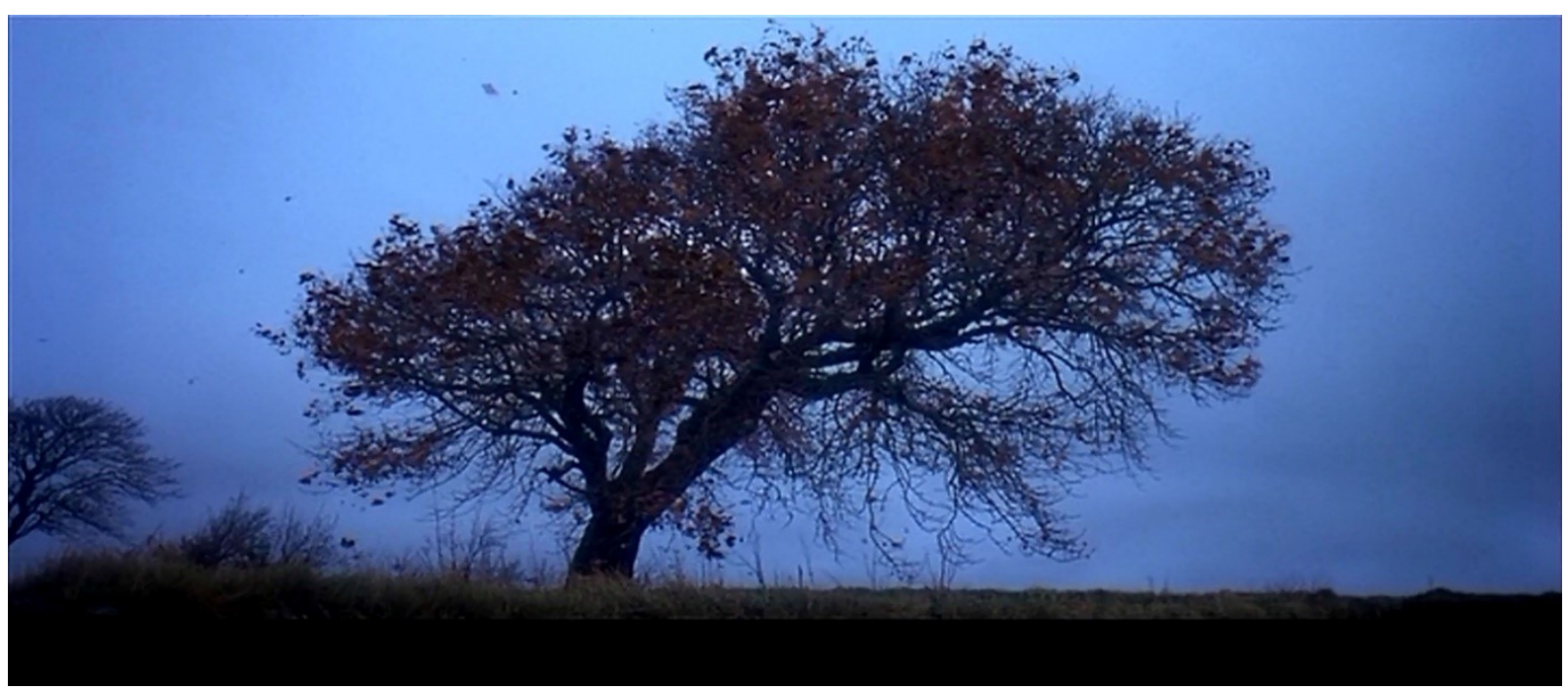

Source: Sylvia (2003).

The film does not quote directly from the book, because the producers could not secure permission from the Plath estate (BRAIN, 2011). Nonetheless, these lines are easily recognized as an adaptation of a famous passage from The Bell Jar, in which its heroine, Esther Greenwood, considers all the possibilities that she has in life through a fig-tree simile; as she is unable to decide between its branches, the figs end up falling at her feet (PLATH, 2005b). Besides, these lines do not echo only The Bell Jar, but also Plath's journals. In an entry that is probably from 1950 , she wrote:

I can never be all the people I want and live all the lives I want. [...] I want to live and feel all the shades, tones, and variations of mental and physical experience possible in my life. And I am horribly limited. [...] I have much to live for, yet unaccountably I am sick and sad. Perhaps you could trace my feeling back to my distaste at having to choose between alternatives. Perhaps that's why I want to be everyone - so no one can blame me for being I. (PLATH, 2000, p. 43-44).

Indeed, this is a recurrent feeling in Plath's journals and in friends' testimonies about her, as I will discuss. Yet, though Sylvia opens with this tree of possibilities, I will argue that the film ends up focusing on just one of its branches: "the man I shall marry." 


\section{Adaptation, historiographic metafiction, and biography}

In $A$ Theory of Adaptation, Linda Hutcheon (2006, p. 7) sees adaptation as "an announced and extensive transposition of a particular work or works." Blurring the boundaries between fiction and reality, she says that "[t]ransposition can also mean a shift in ontology from the real to the fictional, from a historical account or biography to a fictionalized narrative or drama" (HUTCHEON, 2006, p. 8). She later calls this an "ontological shift," which "can happen in adaptations of an historical event or an actual person's life into a reimagined, fictional form" (HUTCHEON, 2006, p. 17). If we think about Sylvia, we might say that the film represents a shift from the real to the fictional, for it fictionalizes Sylvia Plath's life; nevertheless, as I have mentioned, it presents itself as a biopic, and thus it is not exempt from a certain compromise with the truth, as I will further comment. Besides, we might ask where the information for this transposition from "real" to "fictional" is taken from. We know the film to be based on primary and secondary sources such as journals, letters, and biographies. In this case, we could even question whether biographies are not already adaptations of its primary sources, which are, of course, drawn somehow from Plath's life - as it is depicted in journals, letters, and friends' testimonies, for example. By all means, Sylvia is an interpretation and a creation based on sources of different levels. According to Hutcheon (2006, p. 8, emphasis in the original), "as a process of creation, the act of adaptation always involves both (re-)interpretation and then (re-)creation." Ultimately, as a "process of reception, adaptation is a form of intertextuality: we experience adaptations (as adaptations) as palimpsests through our memory of other works that resonate through repetition with variation" (HUTCHEON, 2006, p. 8, emphases in the original). Still for Hutcheon (2006), the task of recognizing and experiencing the film as an adaption or not is for the audience to decide, and they will recognize this kind of intertextuality if they are acquainted with the adapted text. For those of us who are acquainted with Plath's journals, letters, and biographies, Sylvia shows strong intertextuality with these texts; it is as if it is haunted by - or a palimpsest of - those previous narratives, as well as it is a creative interpretation of them. Nevertheless, as any kind of adaptation, it leaves much aside; as I will discuss, it might have cut information of great importance in a poet's life.

Regarding historical characters, in A Poetics of Postmodernism, Hutcheon (2004, p. ix) analyses "historiographic metafiction," which she sees as characterizing postmodernism in fiction. According to her, postmodern theory and art challenges the separation between the literary and the historical, with a focus on what the two share rather than on how they differ; 
there is a desire to close the gap between past and present and to rewrite the past in a new context (HUTCHEON, 2004). Concerning postmodern novels, Hutcheon (2004, p. 119) says that they refer, at the first level, to other texts, and thus "we know the past (which really did exist) only through its textualized remains." This view also applies to postmodern films, for instance, and to postmodern works in general. Regarding historiographic metafiction, she also mentions that it "attempts to demarginalize the literary through confrontation with the historical," and it suggests that discussing fiction in terms of whether it is true or false might not be the best way to do it (HUTCHEON, 2004, p. 108). Rather, "historiographic metafiction plays upon the truth and lies of the historical record," incorporating but rarely assimilating historical details and data, and destabilizing received notions of history and fiction; it "acknowledges the paradox of the reality of the past but its textualized accessibility to us today" (HUTCHEON, 2004, p. 114, emphases in the original) by showing "fiction to be historically conditioned and history to be discursively structured" (HUTCHEON, 2004, p. 120). We only have access to the past through its textual accessibility, a view that blurs the lines between history and fiction, since they are both textually transmitted. Thus, still for Hutcheon (2004, p. 224), historiographical metafiction's relationship with those two discourses "challenges the borders we accept as existing between literature and the extraliterary narrative discourses which surround it: history, biography, autobiography." The lines that divide those discourses are not easy to draw; actually, the point here seems to be whether we can draw them at all. If we think about Sylvia, we might ask: is it fiction? Is it a biography or a biopic? Are biographies and biopics fictional or historical? Where do we draw the line? One might say that this line does not have to be so precisely drawn, but of course there are limits. If we have in mind that the film portrays the life of poet Sylvia Plath, we can always judge its historical (in)accuracies, as long as we have in mind that we cannot judge the film's aesthetic value according to them. Brain (2011, p. 189) seems to share Hutcheon's view on how the success of a work cannot be judged by its historical accuracy: "The measure of success [of a film or a novel] cannot be that everything must be absolutely true and verifiable; this is of course impossible." Nevertheless, this does not stop her from calling attention to the fact that "in terms of the few facts that are absolutely knowable and verifiable, there are inaccuracies in Sylvia" (BRAIN, 2011, p. 189).

Sylvia is presented as a biographical film about Sylvia Plath, as a biopic, and from this particular genre of film - as from biographies - we expect at least a commitment to being historically accurate. When dealing with biopics, I believe it is interesting not to lose track of 
the possibility of a "truth," or at least of a judgement according to a minimal accuracy required. Though a creation, a biopic cannot be seen as fiction as an adaption of a literary work can; it has a certain compromise with a historical character; it helps to shape this character's image, as well as it can be a possible source of knowledge for the ones who want to know her or him better. A distinction that might be interesting here is the one made by Mary E. Hawkesworth (1989, p. 556) between "theories of life" and "theories of literature": "Although both theories of life and theories of literature are necessarily dependent on conceptual schemes that are themselves structured by language and, hence, contestable and contingent, theories of life must deal with more than the free play signifiers." Though both theories of life and theories of literature are linguistically structured, they have different types of commitment. If we treat biographies as part of Hawkesworth's "theories of life," we can say that a biography or a biopic requires a certain compromise with a historical truth. Hawkesworth also mentions:

\begin{abstract}
Although much can be gained from the recognition that there are many sides to every story and many voices to provide alternative accounts, the escape from the monotony of monologue should not be at the expense of the very notion of truth. The need to debunk scientistic assumptions about the unproblematic nature of the objective world does not require the total repudiation of either external reality or the capacity for critical reflection and rational judgment. (HAWKESWORTH, 1989, p. 556).
\end{abstract}

Hawkesworth thus proposes that we stay in-between: while she acknowledges the importance of different discourses as different sources of "truths," she is not ready to entirely give up the possibility of a "truth"; whereas she sees scientific objectivity as problematic and unrealistic, she still believes it must be a goal to at least attempt to, though she acknowledges that it might be unreachable. With this in mind, I recognize that it is important, when dealing with biographies, not to lose track of the notion of "truth," or maybe of an "external reality"; we do not have to believe that there is a single one, that they are not constructed through language, but at least we cannot lose the compromise to what is as accurate as possible when dealing with biographical accounts. In this paper, in consonance with what Hawkesworth (1989, p. 556) calls a "critical feminist epistemology,"3 I intend to elucidate a few aspects of Plath's life that could have been depicted in the film, such as her life before marrying. In other creative women's biopics, such as Julie Taymor's Frida (2002), the artist's life is not reduced to that of a married woman, and Sylvia could also have had a different focus.

\footnotetext{
${ }^{3}$ Hawkesworth's (1989, p. 556) critical feminist epistemology would be between the monolithic "Reason" of scientific discourse and the postmodern view on rejecting the possibility of a "truth": "A critical feminist epistemology must avoid both the foundationalist tendency to reduce the multiplicity of reasons to a monolithic 'Reason' and the postmodernist tendency to reject all reasons tout court."
} 


\section{Sylvia: a postfeminist biopic?}

Sylvia is discussed as an example of a "postfeminist biopic" in Bronwyn Polaschek's 2013 The Postfeminist Biopic. Polaschek (2013, p. 22) sees her book as distancing itself "from an exclusive focus on women directors and from arguments about whether a text is, or is not, feminist," to thus consider "how films produced after second-wave feminism may be marked by this social movement." The author proposes a definition of postfeminist:

\footnotetext{
postfeminist texts are oriented to deconstructing the second-wave feminism of its foremothers. If postfeminism does suggest an epistemological break from earlier forms of feminist theorizing, the feminism is not necessarily undermined; rather the meaning and significance of feminist ideas become the focus of critical reflection. (POLASCHEK, 2013, p. 37).
}

However, though I understand what postfeminism means as a concept, I do not think we are - or maybe that we ever will be - beyond feminism. I am more inclined to agree with Judith Butler, who criticizes feminism from within feminism in Gender Trouble. In a 1999 new preface of the book, she explains that she understood herself "to be in an embattled and oppositional relation to certain forms of feminism," while she also understood "the text to be part of feminism itself" (BUTLER, 2010, p. vii). Thus, I believe that feminist ideas can be the focus of critical reflection from within, and not post, feminism. We could say that the historical shift from second-wave feminism is maybe third-wave feminism, but I do not see feminism as past; it has still much to contribute, even in terms of movements such as transsex and intersex. In the 2004 Undoing Gender, Butler (2004, p. 8) discusses different movements and forms of activism and claims that "[n]one of these movements [such as intersex and transsex] is, in [her] view, post-feminist. They have all found important conceptual and political resources in feminism, and feminism continues to pose challenges to these movements and to function as an important ally." Therefore, if movements as diverse as the transsex and the intersex may still have feminism as their ally, I think the latter has still much to contribute both as a theme to be approached and as a critical strategy to be applied in discussions of creative-women biopics.

Concerning the biopic as a genre, Polaschek (2013, p. 47) sees it as focusing on the biographical journey of the protagonist, by bringing episodes of her life "from childhood or adolescence through to adulthood." However, though she mentions Sylvia as an example, the film never displays Sylvia's childhood or adolescence: it starts when she is already an adult. As an example, whereas the film Frida focuses on important moments of Frida Kahlo's life before her marriage, such as the bus accident, Sylvia leaves aside essential incidents of Plath's 
biography such as her 1953 suicide attempt - a distinction that Polaschek misses. She continues her discussion on the biopic by distinguishing between the female and the feminist biopic, the latter being an empowering rejection of the first, which is somehow reactionary (POLASCHEK, 2013). Whereas the female biopic seems to be rather conservative, with a masculinist view of women and negative feelings towards their reconciliation of creative work and marriage, the feminist biopic apparently shows women as strong, independent, in opposition to the first. The postfeminist biopic would be a third category, which explores feminist biographies while it also challenges them (POLASCHEK, 2013), displaying elements of the female biopic such as the representation of romantic love and madness with a critical feminist frame.

Focusing on Sylvia, Polaschek (2013) calls attention to its emphasis on the relationship between Sylvia Plath and Ted Hughes, which would link the film to the classical female biopic. In fact, director Christine Jeffs describes the film as a "tragic love story" (STUART, 2003 apud POLASCHEK, 2013, p. 66), and scriptwriter John Brownlow (2003

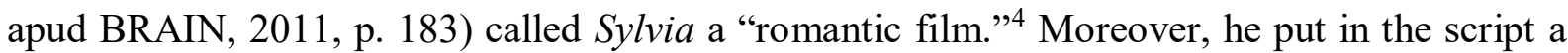
last meeting between Sylvia and Ted the night before she commits suicide, a fact that is in none of Plath's biographies (POLASCHEK, 2013), but he is "absolutely certain that something like that happened" (BORWNLOW, 2003 apud POLASCHEK, 2013, p. 63). ${ }^{5}$ Another important observation made by Polaschek (2013) is the fact that the filmic Sylvia only composes work related to Ted; otherwise she does not appear writing, or writes off screen. Polaschek recognizes that the film conflicts with feminist readings of Plath's work: she sees it as in consonance with books such as Janet Malcolm's and Diane Middlebrook's, which differ from other - more openly feminist - biographies of Plath; both of them "seek to redeem Hughes, and to recast the relationship as one of two poets whose work was mutually beneficial" (POLASCHEK, 2013, p. 65). Furthermore, Polaschek (2013, p. 78) acknowledges that the emphasis on madness in biographies of creative women has been a patriarchal strategy to marginalize their aesthetic work; thus, by depicting madness, she believes that

\footnotetext{
${ }^{4}$ According to Brownlow (2003 apud BRAIN, 2011, p. 188), "the story was blindingly clear ... It was a love story between two giants ... But it was a marriage only one of them could survive." Brain (2011, p. 188) sees Brownlow depicting Plath's life as if it were a soap opera, which results in "the failure to say anything serious or important about the poetry."

${ }^{5}$ This assumption might be due to Ted Hughes's hint of reconciliation between Plath and himself right before she died. In a March 15, 1963 letter to Aurelia Plath, T. Hughes (2007, p. 215) mentions a possible reconciliation but nothing that would give enough details to presuppose a last night together: "all she wanted to say simply was that if I didn't go back to her she could not live. [...] If I hadn't been so blindly involved in the struggle with her, how easily I could have seen through all this! And I had come to the point where I'd decided we could repair our marriage now. She had agreed to stop the divorce."
} 
"Sylvia effaces the significance of feminist interventions, which seek to challenge this form of representation of creative women," calling attention to the fact that "Sylvia's madness as portrayed in the film appears to fuel her creative process." Indeed, Sylvia depicts the character as if she were in a path towards madness, which apparently begins when Sylvia starts to suspect of Ted's infidelity and culminates in the writing of Ariel.

Nonetheless, though the film somehow confirms in the definition of the female biopic, Polaschek (2013, p. 67) sees a certain amount of subversion in Sylvia, such as when Sylvia refuses Ted's attempts to act as her mentor, as well as due to the fact that "Sylvia is not presented as a victim"; actually, "she insists on being recognised for her professional achievements, rather than simply as Ted's wife" (POLASCHEK, 2013, p. 73). Polaschek (2013) sees Sylvia as celebrating Plath's poetic achievements, by constructing her as a Christological heroic biopic protagonist. However, though Sylvia ends with a text that mentions Plath's importance to twentieth-century literature, I do not see many echoes of this importance in the film. We are informed that Plath became famous posthumously, but Sylvia fails in effectively portraying her as a creative woman.

Polaschek (2013, p. 80) mentions that Sylvia "contains feminist elements," but she does not see it as "an overtly feminist version of Sylvia Plath's life"; she justifies this by the fact that the film avoids the logic of blame present in second-wave feminist constructions of Plath. Polaschek (2013) also calls attention to the fact that the film incorporates feminist aspects related to Plath, while it refuses to depict her as a feminist martyr. These views seem to misconceive certain points of feminism. The first argument displays an equivalence between feminism and blaming, which is certainly not a general rule; though I do not see Sylvia as feminist, the fact that it denies a logic of blame is not a reason to say that it is not "overtly feminist." Furthermore, regarding the second argument, we cannot see a film as less feminist because it refuses the role of martyr; martyrdom is not a requirement for a film to be taken as a feminist. I would say that Sylvia fails in such task - which was probably not among its objectives - precisely because it does not portray Plath as the creative woman that she was. This might be due to the texts on which the film was based, which are more interested in her relationship to Hughes than in her achievements as a woman writer.

\section{The silent woman, the Ariel persona, and "Juvenilia"}

If we think of Sylvia as a historiographic metafiction, one of the extra-literary discourses that surround it is Janet Malcolm's 1994 The Silent Woman. It is one of the texts that haunt the film to the extent that it is perceptible to the knowing audience. In fact, 
Malcolm's book is known as a "meta-biography," since it analyses former Plath's biographies. It seems more interested in discussing these biographies than on actually biographing Plath. The author creates Plath as "the silent woman," since we have several voices, and hers is the one that appears the least. Malcolm's emphasis is on Plath's life after she met Hughes: we only have glimpses of what happened to her before she met him. The author focusses on scandals and confusions such as the problem to acquire permission to quote from Plath's works in biographies - the relationship between biographers and the Plath estate was difficult. ${ }^{6}$ Malcolm (2012) is almost anti-feminist at times - in what might be an attempt to improve Hughes's shattered image. She mentions how he lived ten terrible years after Plath's death, and discusses how we tend to be sympathetic towards the dead - which she sees happening in the case of Plath (MALCOLM, 2012). In fact, Malcolm (2012) admits that she has taken the side of the Hughes siblings over Plath.

Sylvia's filmic appearance during her final days finds echo in The Silent Woman: the images bear resemblance to Al Alvarez's description of the way that she looked, especially her loose hair, a description that Malcolm (2012) quotes and comments. The scene in which Plath talks to her downstairs neighbor the night before committing suicide is also well documented in Malcolm's (2012) text. Furthermore, the book brings information on the poet's turn in her creative process. In a letter to Ruth Fainlight, Plath says that she has changed her perception that she could only write when she was happy; she comments that, when Hughes left, the "muse" came to live with her (MALCOLM, 2012). This is in consonance with the idea that Ariel was written under difficult circumstances, as if following a mad creative process, such as presented in Sylvia. Furthermore, according to Malcolm (2012), there seems to be a difference between Hughes the husband and Hughes the literary creator. Following her argument, she comments on how he did not censor Plath's description of an argument that they had in the publication of her abridged journals, because of its literary quality; he even let the passage that mentions that he physically attacked her be published. ${ }^{7}$ This differentiation between husband and literary creator finds echo in one of Sylvia's finals scenes, when Ted touches the Ariel manuscript (Figure 2) as if he were kissing Sylvia's body (Figure 3). Like Malcolm's meta-biography, the film tries to reconcile the image of Hughes as the main editor

\footnotetext{
${ }^{6}$ Olwyn Hughes, Ted Hughes's sister, was the manager of the Plath estate at the time.

${ }^{7}$ Plath's journals were first published in 1982 as The Journals of Sylvia Plath, an abridged version edited by Ted Hughes and Frances McCullough. In 2000, they were published in an unabridged version entitled The Unabridged Journals of Sylvia Plath, edited by Karen V. Kukil.
} 
of Plath's works. ${ }^{8}$ Regarding this scene, Brain (2011, p. 190) observes how Sylvia perpetuates "what is perhaps the most oft-repeated and fallacious link between Plath and her work," for it portrayals the poet and Ariel as the same. Throughout the film, there seems to be an effort in constructing Sylvia as the Ariel persona, ${ }^{9}$ ignoring her former narrative and poetic production - or at least what she wrote before meeting Ted.

Figure 2: Ted (Daniel Craig) touches the Ariel manuscript...

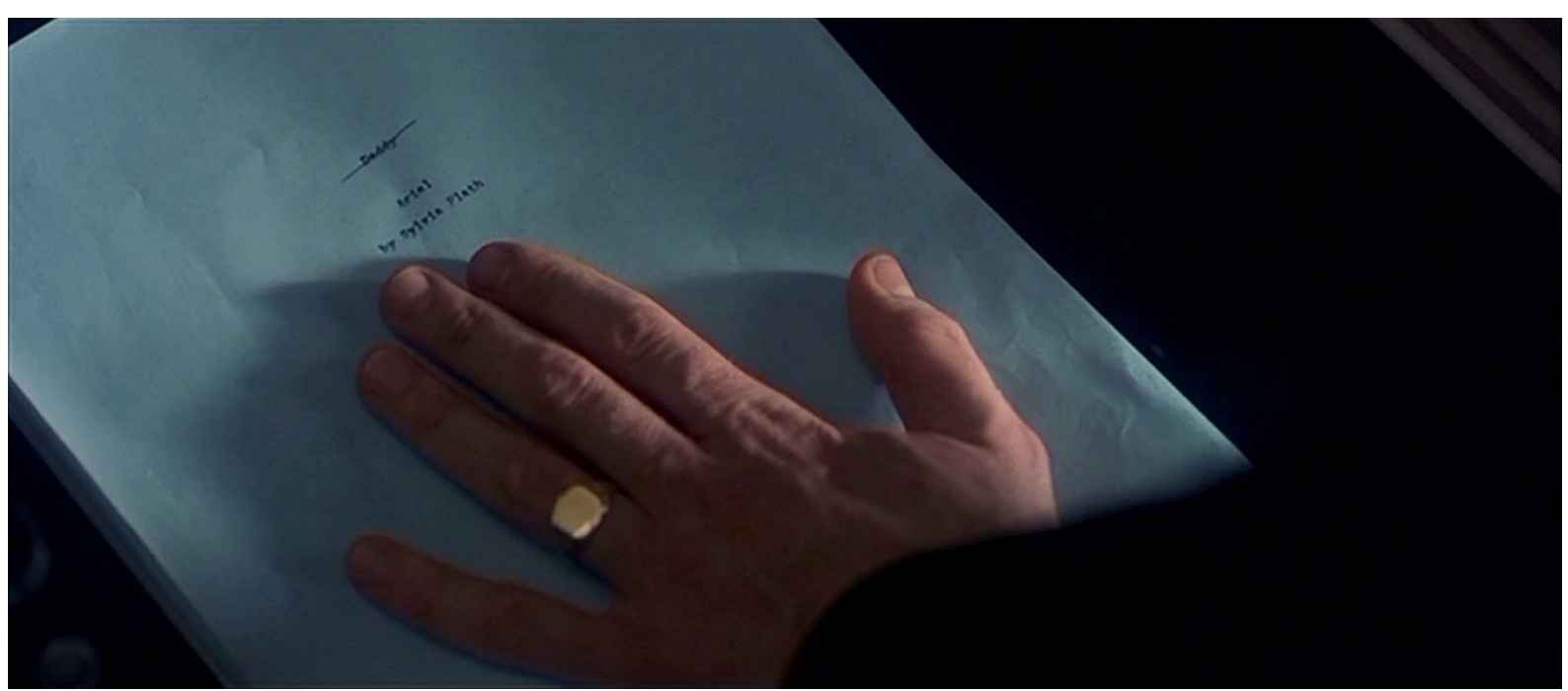

Source: Sylvia (2003).

\footnotetext{
${ }^{8}$ As her husband when Plath died, and thus having the rights to her writings, Hughes was the main editor of her works. However, he has been highly questioned in his craft. The first version of Ariel, edited by him, was published in 1965. It has been discussed for not being the one that Plath let ready before committing suicide. Ariel: The Restored Edition, edited by Plath's daughter, Frieda Hughes, was published in 2004 according to the author's original manuscript (for further discussion on the two Ariel versions, see Bundtzen, The Other Ariel, 2005).

${ }^{9}$ The Ariel persona is generally grounded in a number of its poems that bring dark images, sometimes related to revenge and suicide. There are poems with lighter, more optimistic tones in the book, but the more famous ones have visceral speakers such as those of "Ariel" and "Lady Lazarus," as follows: "And I / Am the arrow, // The dew that flies / Suicidal, at one with the drive/ Into the red // Eye, the cauldron of morning" (PLATH, 2005a, p. 34); "Dying / Is an art, like everything else./ I do it exceptionally well. // I do it so it feels real. / I guess you could say I've a call" (PLATH, 2005a, p. 15).
} 
Figure 3: ...as if he were kissing Sylvia's (Gwyneth Paltrow) body.

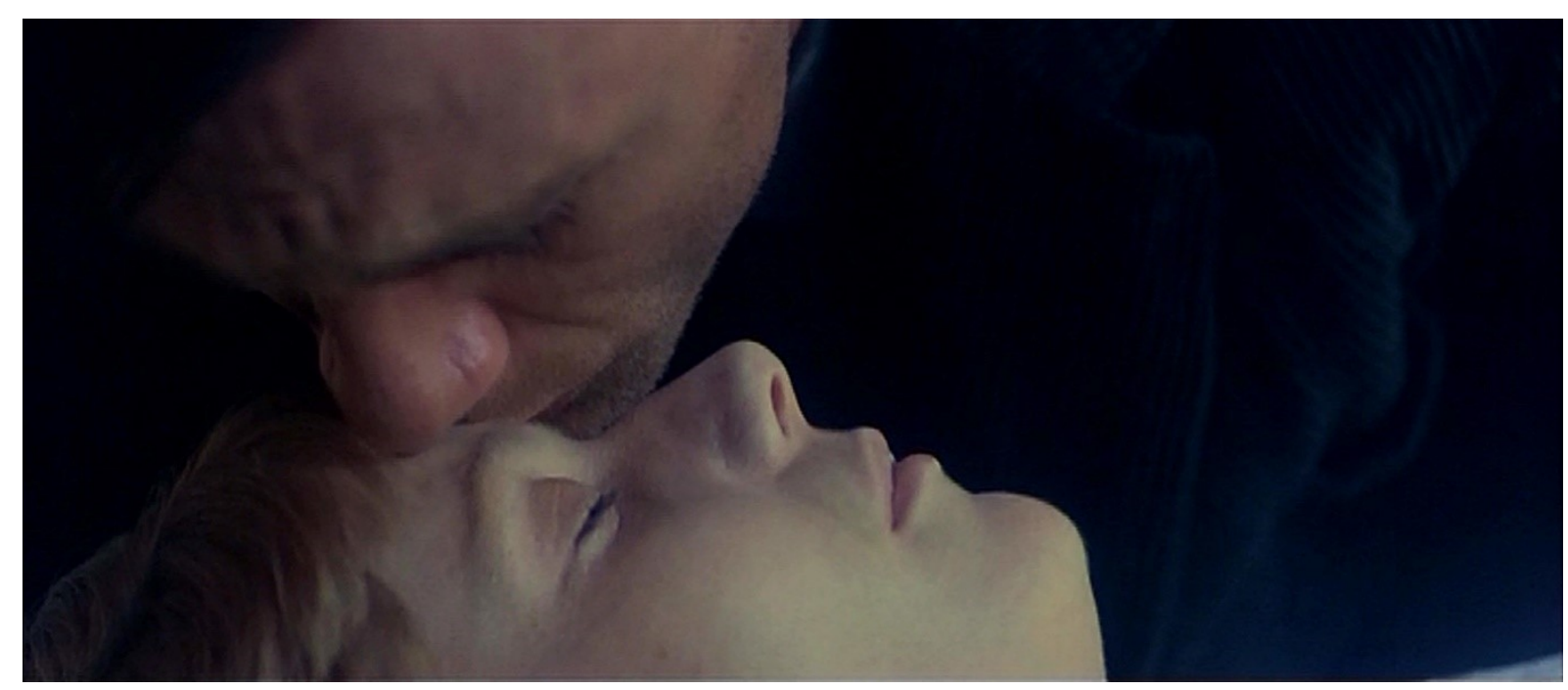

Source: Sylvia (2003).

Plath's collected poetry was edited by Hughes in the 1981 The Collected Poems, which won the Pulitzer Prize. He has been questioned as the editor of this collection, especially for placing fifty of her early poems in an appendix called "Juvenilia." In his introduction to the poetry collection, he justifies his decision:

The first phase might be called her juvenilia and the first slight problem here was to decide where it ended. A logical division occurs, conveniently, at the end of 1955, just after the end of her twenty-third year. The 220 or more poems written before this are of interest mainly to specialists. [...] Nevertheless, quite a few seem worth preserving for the general reader. $[\ldots]$

From this whole pre-1956 period, I have selected what seem to be the best, some fifty pieces, and these are printed - as nearly as possible in the order of their writing - at the back of the book, as an appendix. (T. HUGHES, 2008, p. 15-16) ${ }^{10}$.

Hughes's choice of Plath's "twenty-third year" seems arbitrary, as well as his categorization of these poems as "pre-1956." Interestingly, 1956, the year he chose as the beginning of Plath's adult poetry, is the year in which she met him. As Jo Gill (2008, p. 29) discusses, "[i]n collecting and defining this material as 'Juvenilia,' Hughes has been accused of marginalising anything that Plath wrote in the years before meeting him, in other words, of dating her maturity as an artist to coincide with his involvement in her life and work." Similarly, in Sylvia, Sylvia's life before Ted is put aside, as an appendix, hidden behind all that really matters: we only have access to it through reminiscences in dialogues; all the action

10 David Trinidad (2010, p. 153) comments on how all of Plath's "pre-1956 poems - labeled juvenilia by Hughes" have not yet been "collected and arranged in chronological order." "A 'complete' poems of Sylvia Plath (versus Hughes's 'collected')," Trinidad (2010, p. 153) continues, "would give us a broader picture of Plath's development." 
happens after - or right before - Sylvia met Ted.

\section{Life before Ted}

The fact that Ted Hughes was an important part of Sylvia Plath's life is undeniable. It is also impossible to deny the suffering that having been in the midst of such controversy must have caused, not only to him, but especially to Plath's children. ${ }^{11}$ Nevertheless, it is a fact that these controversies have somehow overshadowed Plath's life before she met Hughes. A more recent biography, Andrew Wilson's 2013 Mad Girl's Love Song: Sylvia Plath and Life before Ted - from which I borrow the title of this work - attempts to fill in this gap: it is the first book to focus exclusively on Plath's life before she met Hughes. Though I find that Wilson overpathologizes Plath, he plays a part in bringing other factors to the discussion of her complexity, thus showing that Hughes was part of much larger life. Wilson avoids secondary sources and brings as primary materials not only journals, letters, and memoirs, but also new interviews with Plath's acquaintances. In this section, I intend to summarize important aspects of Plath's "life before Ted" to show how Sylvia could have avoided many of its problems if it had covered its main character's life before the day she met her future husband.

Whereas Sylvia depicts Plath as struggling to be considered a serious poet, it leaves aside the fact that she had already published while still at school, though mostly in magazines, which were not necessarily literary. She was an excellent student, earning several distinctions, but she also wanted to be popular - and to date several boys. This image of prize-winning Sylvia is very different from her portrayal in Sylvia, especially if we think of its first scene: she seems to be displayed as minor poet - at least in relation to Ted. Wilson $(2013$, p. 2) comments on how Plath was angry that day, February 25, 1956, when Daniel Huws had unfavorably criticized two of her poems, for "she had been writing for publication since the age of eight and she had already earned sizable sums for poems and short stories from Harper's, the Atlantic Monthly, Mademoiselle, and Seventeen." In 1953, Harper's bought three of her poems - her first acceptance in a non-teenage, literary magazine - and she travelled to New York after winning a Mademoiselle contest to work there as a guest editor for a month (WILSON, 2013). When she returned to Smith College - where she was an

\footnotetext{
${ }^{11}$ In her introduction to Plath's Ariel: The Restored Edition, her daughter, Frieda Hughes (2005, p. xx), writes (about a film that could be Sylvia): "My mother's poems cannot be crammed into the mouths of actors in any filmic reinvention of her story in the expectation that they can breathe life into her again, any more than literary fictionalisation of my mother's life - as if writing straight fiction would not get the writer enough notice (or any notice at all) - achieves any purpose other than to parody the life she actually lived. Since she died my mother has been dissected, analysed, reinterpreted, reinvented, fictionalised, and in some cases completely fabricated."
} 
English major - in 1954, she focused on applying for a Fulbright scholarship, which she was granted (WILSON, 2013). She graduated from Smith in 1955, being one of the four summa cum laude graduates that year (WILSON, 2013). According to friend Betsy Wallingford (apud WILSON, 2013, p. 55), Plath "had a great deal of energy, positive energy. She wanted to experiment with everything in life - and whatever she experimented with, she excelled at."

She pictured herself as a writer - an image which oscillated with moments of insecurity. In her first entry in her journal (a 1943 Christmas present from her mother, Aurelia; still unpublished), she made a resolution to, in Wilson's (2013, p. 38) words, "be more pleasant to people; she wanted the world to know she wasn't a snob. She knew she had a tendency to look down on those who weren't as intelligent or well mannered as she was"; in another entry, she wrote that she would be "the world's greatest author and artist" (WILSON, 2013, p. 54). Plath once told Janet Rosenberg that the letters she wrote home from college were for posterity: she wanted to be famous and thought one day someone might want to publish them (WILSON, 2013). She struggled because she wanted perfection in everything: to be a great writer and to have an exciting life. In 1955, she wrote to her benefactress at Smith who would later pay for most of her treatment at McLean hospital ${ }^{12}$ - Olive Higgins Prouty: 'Perhaps the hardest thing I have to accept in life is 'not being perfect' in any way, but only striving in several directions for expression: in living (with people and in the world), and writing, both of which activities paradoxically limit and enrich each other" (PLATH, 1992, p. 201-202). In 1962, when she was already writing the Ariel poems, she told her mother: "I am a writer... I am a genius of a writer; I have it in me. I am writing the best poems of my life; they will make my name. I could finish the novel in six weeks of day-long work. I have a gift of an inspiration for another" (PLATH, 1992, p. 468, emphasis in the original). Brain (2011) uses this quote to reveal Sylvia's inaccuracy regarding Plath's self-image as a writer. In the film, after Sylvia reads "Daddy" to Al Alvarez, she is insecure about her writing. Brain (2011, p. 190) sees the "level of discussion of poetry in Sylvia" as "not high." She mentions how Alvarez himself scorned a dialogue between Sylvia's and his filmic versions, and she also sees other characters' dialogues as not convincing, concluding that Sylvia is "not good art," nor a "good biography" (BRAIN, 2011, p. 191). The fact is that the film was not written for a

\footnotetext{
${ }^{12}$ Plath's economic situation caused her great anxiety throughout her life. With the death of her father, Otto, all the family expenses were on her mother, Aurelia. For her children, Aurelia sacrificed herself, which caused her recurrent ulcer problems; Sylvia was conscious of her mother's economic situation and worried about her: Aurelia even believed that Sylvia wanted to end her life to spare her family from anguish and expense (WILSON, 2013). While hospitalized at the McLean, she was worried about the costs of medical care; in another letter to Olive Higgins Prouty, Plath (1953 apud WILSON, 2013, p. 221) wrote: "This is a nervous breakdown the one illness I several times jokingly said that we could not afford to have."
} 
poetry-reading audience; rather, it was aimed at an audience who wants to see a tragic love story.

Concerning mental illness, Wilson $(2013$, p. 34) calls attention to the fact previously unknown - that even at an early age Plath "seemed to suffer from some sort of mental disturbance"; according to Phillip McCurdy, she tried to cut her throat when she was ten, and to harm herself by cutting her face at the age of fourteen (WILSON, 2013). In 1950, a depressed Plath wrote in her journals:

no matter how enthusiastic you are, no matter how sure that character is fate, nothing is real, past or future, when you are alone in your room [...]. And if you have no past or future which, after all, is all that the present is made of, why then you may as well dispose of the empty shell of present and commit suicide. (PLATH, 2000, p. 30).

As Wilson (2013, p. 163) puts it, "Sylvia had constructed herself to be the best; anything that encroached on her fixed view of herself as a winner threatened her sense of identity." In 1953, when Plath returned home from her Mademoiselle internship, she learned from her mother that she had not been accepted into a short story class at Harvard summer school, to which she had applied; later, Aurelia noticed how Sylvia's joy had left her (WILSON, 2013). She was not well and she knew it, as she put it in her journal: "Right now you are sick in your head. [...] You fool - you are afraid of being alone with you (sic) own mind. [...] Stop thinking selfishly of razors \& self-wounds \& going out and ending it all" (PLATH, 2000, p. 186). In August 1953, Plath tried to kill herself; she was found by her brother two days later (WILSON, 2013). She was hospitalized at the McLean Hospital; there, following a treatment that was apparently not working, she would undergo at least ten electroconvulsive treatment (ECT) sessions, but she showed signs of recovery after only two or three (WILSON, 2013). Her suicide attempt and her following ECT treatment were events that evidently marked Plath's life; they are present in her writings, especially in The Bell Jar, but also in the stories "Tongues of Stone" and "Johnny Panic and the Bible of Dreams" (see Plath's collected narrative, Johnny Panic and the Bible of Dreams, 2008b), among other of her works. In spite of the importance that these moments had in her life, in Sylvia, her suicide attempt comes up only in relation to Ted, when Sylvia explains to him how she acquired a scar in her cheek during the incident.

Other of Plath's concerns were with the hypocrisy of sexual desire and with women having to submit to their husbands' careers. Sylvia rightly shows the poet's apparent ease with her sexuality, as well as her revolt against having to work and take care of the house, while Ted could write. Years before her marriage, Plath was already struggling with these questions. 
As Wilson (2013, p. 7) comments, "[s]ex - or rather the constraints and repression surrounding it - played a central role in Plath's creative and psychological development." In her 1949 (unpublished) journal, she wrote about how she loathed the hypocritical sexual system; she wondered what was wrong in showing love and affection, and expressing desire, while being a woman (WILSON, 2013). Plath's revolt against gender inequalities hit a peak during her relationship with Dick Norton - on which The Bell Jar's character Buddy Willard is based. After sending him a letter, she reflects in her journals:

\begin{abstract}
does it not all come again to the fact that it is a man's world? For if a man chooses to be promiscuous, he may still aesthetically turn up his nose at promiscuity. He may still demand a woman be faithful to him, to save him from his own lust. But women have lust, too. Why should they be relegated to the position of custodian of emotions, watcher of the infants, feeder of soul, body and pride of man? Being born a woman is my awful tragedy. [...] all is spoiled by the fact that I am a girl, a female always in danger of assault and battery. (PLATH, 2000, p. 77).
\end{abstract}

To Ann Davidow, Plath exposed her fear of conforming to the impositions of convention if she chose to be a doctor's - Dick's - wife; Plath also told her that she was too selfish to be crushed by the demands of a man and his career (WILSON, 2013). According to Jane Anderson (1986 apud WILSON, 2013, p. 129), Dick "wanted a woman to be a full-time wife and mother." It is thus not a surprise that Plath later decided that she could never marry him. In the 1950s, college education for women was seen as a preparation for marriage and motherhood; Plath, nevertheless, "saw no reason why she couldn't have a stimulating career and a husband and family" (WILSON, 2013, p. 191, emphasis in the original). Plath wanted it all: to have a social life and to be an excellent writer; to marry, have children, and to be famous by her craft. In Sylvia, we see a woman exhausted for wanting to perform several tasks with perfection, which was, of course, impossible.

However, though Plath's exhaustion is well presented in the film, Sylvia's sex life is somehow inaccurate, since it is centered on Ted. Wilson (2013, p. 6) calls attention to the fact that Hughes was not the only man in Plath's life: "before she met him she had gone out with literally hundreds of men - some who were innocent dates, others who were more serious"; she actually went "from one heartthrob to another," a friend once noting that she was "boy crazy" (WILSON, 2013, p. 67-68). In Sylvia, this is again only portrayed in relation to Ted, when Aurelia mentions to him that "there were a lot of other boys. But, they didn't scare her. She rather frightened them, I think. You're... you're very different. I think you frightened her and that's why she likes you" (SYLVIA, 2003, ch. 5). When Plath was younger, she was very preoccupied with what not to do - she was terrified of getting pregnant. After leaving the 
McLean, nevertheless, she suddenly opened sexually; Ruth Beuscher, her psychiatrist, tried to persuade her not to suppress her "erotic urges" (WILSON, 2013, p. 232). Plath would then feel freer to consummate her sexual desires with different men. In 1954, she met Richard Sassoon, who would have a major role among her dates; she went to New York to see him, and they spent most of the time in bed together (WILSON, 2013). However, he was not the only man she dated at the time. When Plath attended Harvard summer school, she met a man who introduced himself as a science professor, Edwin Akutowicz, in whom she would base The Bell Jar's character Irwin; similarly to the novel, after spending the night with Edwin, Plath hemorrhaged badly (WILSON, 2013).

Regarding Hughes, in the night that they met, he was not the only one to come home with a date - as happens in Sylvia - Plath was also seeing someone that night. It was a man named "Hamish," as she mentions in her journal: "then we went to Hamish's room and lay on the floor by the fire and I was just so damn grateful for his weight on me and his mouth which was nice, and begged that he scold me, and he just said I wasn't a whore or a slut like I said" (PLATH, 2000, p. 213-214). Plath somehow saw herself as a "slut" for exploring her sexuality, but this did not prevent her from fulfilling her desires; she actually seemed to joke about it. In spite of Hamish and of her sudden passion for Hughes, Plath's love at the time appeared to be directed towards Sassoon: after sleeping with Hughes one day, she went straight to Paris to see Sassoon, without knowing that he was in Spain (WILSON, 2013). She wrote in her journal: "Arrived in Paris early Saturday evening exhausted from sleepless holocaust night with Ted in London [...] I took myself in leash \& washed my battered face, smeared with a purple bruise from Ted and my neck raw and wounded too, and decided to walk out toward Richard's" (PLATH, 2000, p. 552). She did not see the least problem in describing her "sleepless holocaust night" with Hughes while commenting on her quest for Sassoon, whom she did not find in the end. In her journal, Plath $(2000$, p. 567) said that "if he [Sassoon] would come today I would stay here with him." However, what would have happened if Plath had found Sassoon we will never know, and it is beside the point. What we do know is that she had options at the time; though she felt strongly connected to Hughes, she flirted with these other possibilities. She had recently travelled through Europe with an old boyfriend, Gordon Lameyer. Her choices at the time, as Wilson (2013, p. 312) summarizes, were between Richard, Gordon, and Ted: "If Sassoon returned from Spain, she would, she said, fall into his arms; Lameyer was, she knew, no longer an option for her, as she could hardly hide her dislike for him. That meant that there was, in her mind, only one man for her: 


\section{Ted Hughes."}

It is interesting that Wilson chose to end his last chapter by hinting that Hughes was only one of Plath's options. This implies that maybe it was a coincidence that they ended up together, that he was not the reason of her existence, nor that - absurdly as Sylvia puts it before they met they were two "halves." In the film, during the night that Sylvia and Ted spend together before she commits suicide - the night that Brownlow created, which hints that maybe Sylvia died for Hughes - she tells him: "God, I've missed you! I almost went mad. We're not even two people. Even before we met, we were just those two halves walking around, with big gaping holes in us shaped like the other person. And then we found each other and we were finally a whole" (SYLVIA, 2003, ch. 15). It seems rather unlikely that Plath, who went to meet Sassoon after a "holocaust night" with Hughes, would see herself as just a "half" before having found him. Anyhow, this quote is an example of how Sylvia focuses on Ted to an extent that maybe Sylvia \& Ted - rather than just Sylvia - would be a better title for the film.

\section{Conclusion: the biopic of a poet?}

Sylvia Plath wanted to live a full life; to experience it all to an extent that sometimes paralyzed her, which finds echo in the The Bell Jar's fig-tree passage. She saw herself as having different selves, as undecided when it came to choose one of them. Sylvia apparently makes this choice for her by choosing that of a wife. Her roles as daughter and as mother are put aside, and Ted is as an important a character as Sylvia in a biopic that is supposed to be about her. This is precisely the problem of Sylvia: it presents itself as a biopic of a creative woman, while it actually works as a tragic love story. In spite of its criticism directed to the institution of marriage, it is centered in a relationship, rather than in a woman's life. It is certainly hard to posit Sylvia as a feminist biopic; nevertheless, I do not follow Polaschek's classification of it as postfeminist. In general, the film is more similar to what this author defines as the classical female biopic, because of its focus on romance, though it has its feminist moments.

Those acquainted with the tradition of Plath's biographies watch Sylvia as a palimpsest, as haunted by a few texts published on her life. The texts chosen were the ones focused on Hughes, and this might be the reason why this was the film's cut. Nevertheless, Plath's writings are almost absent from it, which can be due to the fact that the production was not allowed to quote from her poems and prose. When Sylvia does deal with poetry, it is only superficially; the film is intended for an audience who is more interested in romance than 
in literature. Moreover, in spite of its inability to discuss a poem, when Sylvia brings up poetry it is to somehow equalize Plath's writing career to Ariel, and herself to its persona. Overall, what is lacking in Sylvia is the poet's "Juvenilia." Similarly to what Hughes's editing does to her collected poetry, the film puts aside her life before she met him. Evidently, there were several other important events that constituted Plath as an individual. In this work, I have tried to come up with a few incidents of her life that might have been depicted in Sylvia - or that at least change our perception of the film's portrayal of her. What I see in Sylvia are several images of a jealous wife waiting for her husband to come home - which did happen but almost none of a poet reading and writing. This seems odd - to say the least - in a biopic about one of the most famous American poets of the twentieth century.

\section{Acknowledgments}

I would like to thank Professor Elaine Barros Indrusiak, for introducing me to biopic studies, and Professor Rita Terezinha Schmidt, for helping me shape a critical feminist perspective for this text.

\section{References}

BRAIN, Tracy. Fictionalizing Sylvia Plath. In: BAYLEY, Sally; BRAIN, Tracy (Eds.). Representing Sylvia Plath. Cambridge: Cambridge University, 2011, p. 183-202.

BUNDTZEN, Lynda K. The Other Ariel. Sparkford: Sutton Publishing, 2005.

BUTLER, Judith. Gender Trouble: Feminism and the Subversion of Identity. New York: Routledge, 2010. . Undoing Gender. New York: Routledge, 2004.

FRIDA. Directed by Julie Taymor. Screenplay by Clancy Sigal, Diane Lake, Gregory Nava and Anna Thomas. Performances by Salma Hayek, Alfred Molina and Antonio Banderas. Imagem Filmes, 2002. DVD.

GILL, Jo. The Cambridge Introduction to Sylvia Plath. Cambridge: Cambridge University Press, 2008.

HAWKESWORTH, Mary E. Knowers, Knowing, Known: Feminist Theory and Claims of Truth. Signs, v. 14, n. 3, Spring 1989, p. 533-557. Available at: $<$ http://www.jstor.org/stable/3174401>. Accessed: 18/05/2017.

HUGHES, Frieda. Foreword. In: PLATH, Sylvia. Ariel: the Restored Edition. Edited by Frieda Hughes. New York: Harper Collins Publishers, 2005, p. xi-xxi.

HUGHES, Ted. Introduction. In: PLATH, Sylvia. The Collected Poems. Edited by Ted Hughes. New York: Harper Collins Publishers, 2008, p. 13-17. 
Faber, 2007.

Letters of Ted Hughes. Selected and edited by Christopher Reid. London: Faber and

HUTCHEON, Linda. A Poetics of Postmodernism: history, theory, fiction. New York: Routledge, 2004.

. A Theory of Adaptation. New York: Routledge, 2006.

MALCOLM, Janet. A Mulher Calada: Sylvia Plath, Ted Hughes e os Limites da Biografia (Original: The Silent Woman: Sylvia Plath \& Ted Hughes). Translation by Sergio Flaksman. São Paulo: Companhia das Letras, 2012.

PLATH, Sylvia. Ariel. London: Faber \& Faber, 2009.

Ariel: the Restored Edition. Edited by Frieda Hughes. New York: Harper Collins Publishers, 2005a.

. The Bell Jar. New York: Harper Collins Publishers, 2005b.

2008a.

. The Collected Poems. Edited by Ted Hughes. New York: Harper Collins Publishers,

. Johnny Panic and the Bible of Dreams. Edited by Ted Hughes. New York: Harper Perennial, 2008b.

The Journals of Sylvia Plath. Edited by Ted Hughes and Frances McCullough. New York: Dial, 1982.

. Letters Home: Correspondence 1950-1963. Edited by Aurelia Schober Plath. New York: Harper Perennial, 1992.

. The Unabridged Journals of Sylvia Plath. Edited by Karen V. Kukil. New York: Anchor Books, 2000.

POLASCHEK, Bronwyn. The Postfeminist Biopic: narrating the lives of Plath, Kahlo, Woolf and Austen. Basingstoke: Palgrave Macmillan, 2013.

SYLVIA: Paixão Além das Palavras (Original: SYLVIA). Directed by Christine Jeffs. Screenplay by John Brownlow. Performances by Gwyneth Paltrow and Daniel Craig. Imagem Filmes, 2003. DVD.

TRINIDAD, David. Hidden in Plain Sight: On Sylvia Plath's Missing Journals. Plath Profiles: An Interdisciplinary Journal for Sylvia Plath Studies, v. 3, Fall 2010, p. 124-157. Available at: <https://scholarworks.iu.edu/journals/index.php/plath/article/view/4514>. Accessed: 31/07/2017.

WILSON, Andrew. Mad Girl's Love Song: Sylvia Plath and Life before Ted. New York: Scribner, 2013.

Image credits: Figures 1, 2, and 3 are stills taken from SYLVIA: Paixão Além das Palavras (English: SYLVIA). Directed by Christine Jeffs. Screenplay by John Brownlow. Performances by Gwyneth Paltrow and Daniel Craig. Imagem Filmes, 2003. DVD. 


\section{Sylvia e a ausência de vida antes de Ted}

Resumo: Como Bronwyn Polaschek menciona em The postfeminist biopic, o filme Sylvia (Christine Jeffs, 2003) é baseado em biografias de Sylvia Plath que focam em seu relacionamento com o marido Ted Hughes - como é o caso de A mulher calada, de Janet Malcolm. Neste artigo, fundamentado nos trabalhos de Linda Hutcheon, Mary E. Hawkesworth e Tracy Brain, argumento que essa biografia funciona como um palimpsesto de Sylvia e que o filme constrói Plath como a persona de Ariel, negligenciando sua "Juvenilia" sua poesia inicial, conforme definida por Hughes. De fato, Sylvia deixa de fora os primórdios da vida de Plath - antes de ela conhecer Hughes - e acaba, assim, retratando-a mais como esposa do que como escritora. Por fim, ao trazer informações sobre a vida de Plath antes de ela conhecer Hughes de uma biografia mais recente (de Andrew Wilson), analiso como uma imagem diferente de Plath poderia ter sido criada se essa parte de sua vida não estivesse ausente do filme.

Palavras-chave: Sylvia. Sylvia Plath. Estudos de adaptação. Biopic. Crítica feminista.

Recebido em: 15/08/2017

Aceito em: 17/01/2018

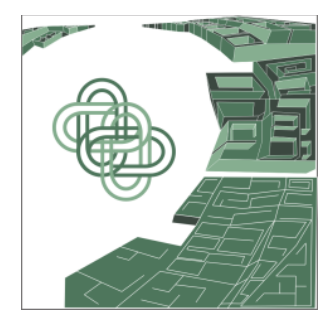

